\title{
Respon Masyarakat Terhadap Madrasah Takmiliyah di Kabupaten Rejang Lebong
}

\author{
Syaiful Bahri \\ Sekolah Tinggi Agama Islam Negeri (STAIN) Curup \\ hajisyaiful11@gmail.com
}

\begin{abstract}
Madrasah Diniyah Takmiliyah (MDT) is a non-formal education which is the solution of the lack of hours of religious study at school. The Historically, this solution is to accommodate the numerous demands of various elements of society that have been raised through; demonstrations, rallies, suggestions, and even pressure on the government.Madrasah education Diniyah Takmiliyah (MDT) in the history of education entirely an initiative of the Muslim community. The Unit MDT Education with a strong legal umbrella among such as; the provisions in the Act No. 20 of 2003 on National Education system, Government Regulation No. 55 of 2007 on Religious Education and Religious Education, Government Regulation No. 48 of 2008 concerning education funding, as well as the Minister of Religious Affairs regulation No. 13 of 2014 concerning Islamic Religious Education. In Kabupaten Rejang Lebong MDT are 15 institutions. Where the community's response to MDT is perceived as lacking, the management of MDT management is very simple and even tends to be traditional, the holding factor of MDT is strong enough and the factor of inhibiting the low awareness of the community and the difficulty of getting the fund, and the solution for the society to address the lack of religious learning hours at the majority school of apathetic parents religious learning outcomes at school, a small part of sending their children to the MDT, and a few more parents teaching their own children at home. This research is a field research associated with various existing literatures, the aims to contribute to the public as general, STAIN Curup, and Local Government Rejang Lebong Regency.
\end{abstract}

Keywords : Takmiliyah Diniyah Education, Responses Communities

\begin{abstract}
Abstrak : Pendidikan Madrasah Diniyah Takmiliyah (MDT) adalah pendidikan nonformal yang merupakan solusi dari kekurangan jam belajar agama pada sekolah. Dalam sejarahnya solusi ini adalah mengakomodir banyaknya sejumlab tuntutan dari berbagai elemen masyarakat yang banyak dikemukakan melalui; demo, unjuk rasa, usul, babkan sampai desakan kepada pemerintah. Pendidikan Madrasah Diniyah Takmiliyah (MDT) merupakan lembaga satuan pendidikan sepenubnya merupakan inisiatif masyarakat muslim. Satuan Pendidikan MDT dengan payung bukum yang cukup kuat antara lainnya; Undang-Undang Nomor : 20 tahun 2003 tentang sistem Pendidikan Nasional, Peraturan Pemerintah Nomor 55 tahun 2007 tentang Pendidikan Agama dan Pendidikan Keagamaan, Peraturan Pemerintah RI Nomor 48 tabun 2008 tentang pendanaan pendidikan, serta peraturan Menteri Agama RI Nomor 13 tabun 2014 tentang Pendidikan Keagamaan Islam. Di Kabupaten Rejang Lebong MDT sebanyak 15 lembaga. Dimana respon masyarakat terhadap MDT dirasakan kurang, manajemen pengelolaan MDT sangat sederhana babkan cendrung tradisional, faktor pendungkung penyelenggaraan MDT cukup kuat dan faktor penghambat rendahnya kesadaran masyarakat serta sulitnya mendapatkan dana, serta solusi bagi masyarakat menyikapi kurangnya jam belajar agama pada sekolah mayoritas orangtua apatis menerima saja hasil pembelajaran agama pada sekolah, sebagian kecil menyekolabkan anaknya di MDT, dan sebagian kecil lagi orangtua mengajari anaknya sendiri di rumah. Penelitian ini adalah merupakan penelitian lapangan atau field research yang dibubungkan dengan berbagai literatur yang ada, bertujuan untuk memberikan kontribusi kepada masyarakat secara umum, STAIN Curup, dan Pemerintah Daerah Kabupaten Rejang Lebong.
\end{abstract}

Kata Kunci : Pendidikan Diniyah Takmiliyah, Respon Masyarakat 


\section{Pendahuluan}

Pendidikan adalah sebuah proses yang merupakan investasi jangka panjang, dimana hasilnya akan dapat dirasakan dalam waktu dan dekade yang cukup lama. Pendidikan Islam di Indonesia merupakan warisan peradaban Islam dan sekaligus aset bagi pembangunan pendidikan nasional. Sebagai warisan, ia merupakan amanat sejarah untuk dipelihara dan dikembangkan oleh umat Islam dari masa ke masa. Sedangkan sebagai aset, pendidikan Islam yang tersebar di berbagai wilayah ini membuka kesempatan bagi bangsa Indonesia untuk menata dan mengelolanya, sesuai dengan sistem pendidikan nasional.

Dalam kedua perspektif di atas, pendidikan Islam di Indonesia selalu menjadi lahan pengabdian kaum muslimin dan sekaligus menjadi bagian integral dari sistem pendidikan nasional.

Di Indonesia, sebagai negara yang berlandaskan Pancasila, fungsi pendidikan tidak hanya diarahkan untuk menyiapkan generasi penerus yang memiliki tingkat intelektualitas yang tinggi, menguasai dinamika perkembangan ilmu pengetahuan dan teknologi. Namun lebih dari itu, tujuan pendidikan yang diselenggarakan harus memastikan hadirnya insan-insan taqwa. Dimana pendidikan adalah usaha sadar dan terencana, sebagaimana dimaksudkan Undang-Undang Nomor 20 tahun 2003 tentang Sistem Pendidikan Nasional pasal 1 ayat 1 yang berbunyi :

"Pendidikan adalah usaha sadar dan terencana untuk mewujudkan suasana belajar dan proses pembelajaran agar peserta didik secara aktif mengembangkan potensi dirinya untuk memiliki kekuatan spiritual keagamaan, pengendalian diri, kepribadian, kecerdasan, akhlak mulia, serta keterampilan yang diperlukan dirinya, masyarakat, bangsa dan Negara" ${ }^{1}$

Karena itu pendidikan yang layak adalah hak dari setiap warga Negara Republik Indonesai sebagaimana dimaksud Undang-Undang nomor 20 tahun 2003 pasal 5 ayat 1 : "Setiap warga Negara mempunyai hak yang sama untuk memperoleh pendidikan yang bermutu", dan dalam merealisasikan proses pendidikan tersebut semua pihak ikut serta berperan sebagaimana dimaksud Undang-Undang Sisdiknas nomor 20 tahun 2003 pasal 7 ayat 1 Jo pasal 8 dan pasal 10 :

Pasal 7 ayat 1: "Orang tua berhak berperan serta dalam memilih satuan pendidikan dan memperoleh informasi tentang perkembangan pendidikan anaknya, pasal 8 : Masyarakat berhak berperan serta dalam perencanaan, pelaksanaan, pengawasan, dan evaluasi program pendidikan, dan pasal 10 : Pemerintah dan pemerintah daerah berhak mengarahkan, membimbing,

\footnotetext{
${ }^{1}$ Departemen Agama RI, Undang-Undang Nomor 20 tahun 2003, 2006, hal.46

${ }^{2}$ Departemen Agama RI, Undang-Undang RI Nomor 20 tahun 2003, 2006, hal.49
} 
membantu, dan mengawasi penyelenggaraan pendidikan sesuai dengan peraturan perundang-undangan yang berlaku" ${ }^{3}$

Dari penjelasan beberapa pasal di atas menunjukkan bahwa setiap warga negara berhak mendapatkan pendidikan yang layak. Proses penyelenggaraan pendidikan adalah tanggung jawab bersama mulai dari masyarakat, orang tua, pemerintah, baik pemerintahan pusat maupun pemerintahan daerah, sebagaimana dimaksud oleh Peraturan Pemerintah RI Nomor 48 tahun 2008 tentang Pendanaan Pendidikan pasal 2 : (1) yang berbunyi : "Pendanaan Pendidikan menjadi tanggung jawab bersama antara Pemerintah, Pememerintah daerah, dan masyarakat"

Salah satu lembaga pendidikan keagamaan yang sudah cukup lama berkifrah di tengah-tengah masyarakat muslim di Indonesia adalah Pendidikan Madrasah Diniyah Takmiliyah (MDT). Pendidikan Madrasah Diniyah Takmiliyah tersebut adalah pendidikan keagamaan nonformal sebagai suplemen (tambahan) dalam rangka memberikan kesempatan bagi anak yang didalam menempuh pendidikan agama pada sekolah dirasa sangat kekurangan jam pada mata pelajaran pendidikan agama sehingga dapat memanfaatkan lembaga pendidikan dimaksud. Eksistensi MDT sangat kuat sebagaimana dimuat pada pasal 45 ayat 1: "pendidikan Diniyah nonformal diselenggarakan dalam bentuk: a.madrasah diniyah takmiliyah,b. pendidikan $\mathrm{Al}$ Quran, c. majelis taklim; atau d. pendidikan keagamaan Islam lainnya"

Satuan pendidikan Madrasah Diniyah Takmiliyah adalah lembaga yang sampai hari ini semuanya diselenggarakan oleh masyarakat muslim, populasinya begitu menjamur seperti jamur tumbuh dimusim hujan pada kisaran 10 sampai 5 tahunan yang lalu di beberapa provinsi seperti; Provinsi Jawa Barat, Jawa Timur, Jawa Tengan dan beberapa Provinsai lainnya termasuk di Provinsi Bengkulu. Walau dengan fasilitas dan birograsi yang sangat sederhana namun sangat memberikan manfaat bagi anak didik atau santrinya dalam pembekalan ilmu agama dasar yang berimbas pada pembentukan akhlak yang baik bagi santrinya. Tetapi sangat disayangkan pendidikan pada Madrasah Diniyah Takmiliyah ini untuk di Provinsi Bengkulu umumnya dan khususnya di Kabupaten Rejang Lebong kurang mendapat respon dalam wujud dimanfaatkan dengan maksimal baik oleh orangtua dan anak maupun para pemerhati pendidikan agama Islam dengan indikator jumlah lembaganya kalaupun bertambah sangat tidak seberapa bila dibanding dengan pertumbuhan jumlah anak-anak, begitu pula dalam jumlah santrinya, dengan indikasi sangat banyaknya anak-anak usia sekolah dasar

\footnotetext{
${ }^{3}$ Ibid, hal.46 dan 50

${ }^{4}$ Departemen Pendidikan Nasional, Peraturan Pemerintab RI Nomor 48 tabun 2008, 2008, hal.11

${ }^{5}$ Ibid. , hal.11
} 
yang bermain dan berkeliaran di sekitar dimana kita berada pada sore hari setelah pulang dari sekolah pagi harinya dengan tidak memanfaatkan waktu untuk mengikuti pendidikan dimaksud. Hal ini mengindikasikan bahwa mereka tidak memanfaatkan waktu sehabis pulang dari proses pembelajaran pada sekolah, untuk mengikuti pendidikan Madrasah Diniyah Takmiliyah (MDT) dimana tempat mereka tinggal. Berdasarkan data dan penelusuranpenulis di lapangan MDT di Kabupaten Rejang Lebong sebanyak 15 lembaga.

Dari data tersebut, dapat kita lihat bahwa sisi jumlah lembaga MDT nya sangat sedikit sekali jika ingin kita bandingkan dengan luas wilayah dengan jumlah desa / kelurahan dan kecamatan bahkan ada beberapa kecamatan yang sama sekali tidak ada lembaga MDT nya seperti; Kecamatan Bermani Ulu Raya, Kecamatan Sindang Kelingi, Kecamatan Kota Padang, Kecamatan Binduriang, Kecamatan Sindang Beliti Ilir, Kecamatan Curup Utara, dan Kecamatan Kecamatan Padang Ulak Tanding.

Selanjutnya berdasarkan hasil penelusuran penulis pada saat melakukan observasi di lapangan ketika mewawancarai dari beberapa informan, didapati pula menurut salah satu guru yang sekaligus wakil kepala MDT Aisyiah di Kelurahan Tempel Rejo bernama Niti Hartati, S.Pd bahwa "mayoritas masyarakat termasuk para guru MDT sendiri belum semua mengetahui dan paham akan eksistensi MDT tersebut merupakan pendidikan suplemen (tambahan) karena dirasakan kurang jam belajar agama Islam pada sekolah yang hanya 2 jam seminggu, kami-kami ini yang mengajar pada MDT hanya meneruskan kegiatan lembaga MDT ini dan kami tidak tahu bahwa MDT ini sebegitu pentingnya." ${ }^{\prime 6}$

Semenjak lahirnya Undang-Undang Sisdiknas Nomor 20 tahun 2003 dan lebih spesifik lagi dapat kita lihat, sebagaimana dimaksud pada pasal 21 ayat 1 Peraturan Pemerintah Nomor 55 tahun 2007 Jo pasal 21 Peraturan Menteri Agama RI Nomor 13 tahun 2014 yang menyatakan :

Pasal 21 ayat 1 :"Pendidikan diniyah nonformal diselenggarakan dalam bentuk pengaiian kitab, Majelis Taklim, Pendidikan Al-Quran, Diniyah Takmiliyah atau bentuk lain yang sejenis" "dan pasal 45 ayat 1 : Pendidikan diniyah nonformal diselenggarakan dalam bentuk : Pengajian kitab, Majelis taklim, Pendidikan Alquran, Diniyah Takmiliyah, atau bentuk lain yang sejenis" 8

Karena itu peneliti tertarik melakukan penelitian tentang bagaimana respon masyarakat terhadap pendidikan Madrasah Diniyah Takmiliyah di

\footnotetext{
${ }^{6}$ Wawancara pada tanggal 03 Agustus 2017

${ }^{7}$ Departemen Agama RI, Peraturan Pemerintah Nomor 55 tabun 2007, 2006 hal. 21

${ }^{8}$ Kementerian Agama RI, Peraturan Menteri Agama RI Nomor 13 tabun 2014, hal. 55
} 
Kabupaten Rejang Lebong, bagaimana manajemen Madrasah Diniyah Takmiliyah di Kabupaten Rejang Lebong, apa faktor pendukung dan faktor penghambat pelaksanaan MDT Kabupaten Rejang Lebong, serta adakah solusi bagi masyarakat menyikapi kekurangan jam belajar agama pada sekolah. Selanjutnya diharapkan melalui penelitian ini, peneliti ingin mengetahui bagaimana respon masyarakat terhadap pendidikan Madrasah Diniyah Takmiliyah di Kabupaten Rejang Lebong, menjelaskan manajemen Madrasah Diniyah Takmiliyah di Kabupaten Rejang Lebong, memaparkan faktor pendukung dan faktor penghambat penyelenggaraan pendidikan Madrasah Diniyah Takmiliyah di Kabupaten Rejang Lebong, serta mencari tahu apakah ada solusi bagi masyarakat dalam menyikapi kurangnya jam belajar agama pada sekolah.

\section{Rumusan Masalah}

1. Bagaimana respon masyarakat terhadap pendidikan Madrasah Diniyah Takmiliyah di Kabupaten Rejang Lebong ?

2. Bagaimana manajemen Madrasah Diniyah Takmiliyah di Kabupaten Rejang Lebong?

3. Apa faktor pendukung dan faktor penghambat pelaksanaan MDT Kabupaten Rejang Lebong?

4. Adakah solusi bagi masyarakat menyikapi kekurangan jam belajar agama pada sekolah?

Fokus penelitian ini adalah hanya meneliti dan membahas pendidikan Madrasah Diniyah Takmiliyah yang disingkat dengan (MDT) saja. Karena jika berbicara Madrasah Diniyah ada Madrasah Diniyah formal pada Pondok Pesantren dan ada Madrasah Diniyah nonformal di Luar Pondok Pesantren. Selanjutnya walaupun ada pengungkapan kedua Madrasah Diniyah tersebut, itu hanya merupakan upaya memperkenalkan sekilas saja.

\section{Tujuan Penelitian}

1. Mengetahui bagaimana respon masyarakat terhadap pendidikan Madrasah Diniyah Takmiliyah di Kabupaten Rejang Lebong;

2. Menjelaskan manajemen Madrasah Diniyah Takmiliyah di Kabupaten Rejang Lebong;

3. Memaparkan faktor pendukung dan faktor penghambat penyelenggaraan pendidikan Madrasah Diniyah Takmiliyah di Kabupaten Rejang Lebong;

4. Mencari tahu apakah ada solusi bagi masyarakat dalam menyikapi kurangnya jam belajar agama pada sekolah.

\section{Kontribusi Penelitian}

a. Teoritis :

1. Dapat memberikan sumbangan pengetahuan di bidang keilmuan tentang penyelenggaraan pendidikan Madrasah Diniyah Takmiliyah;

2. Dapat menjadi bahan kajian untuk penelitian selanjutnya. 
b. Praktis :

1. Bagi Pemerintah Daerah Kabupaten Rejang Lebong, penelitian ini untuk mengkomunikasikan sekaligus dukungan pada salah satu visi nya yang mengusung "mewujudkan masyarakat Rejang Lebong yang religius" melalui pendidikan Madrasah Diniyah Takmiliyah;

2. Bagi lembaga STAIN Curup sebagai sebuah penelitian yang bermanfaat untuk dijadikan motivasi yang kuat terhadap para siswa pendidikan sekolah umum agar memiliki pengetahuan agama Islam dengan jenjang yang ada sehingga apabila melanjutkan pendidikan pada STAIN Curup khususnya, tidak mengalami kesulitan pada beban mata kuliah ke STAIN an seperti yang dirasakan sekarang;

3. Bagi peneliti, dapat dijadikan sebagai modal awal referensi wawasan ilmiah mengenai penyelenggaraan pendidikan Madrasah Diniyah Takmiliyah.

\section{Diskripsi Teoritik}

Penelitian ini merupakan penelitian lapangan, peneliti melakukan penelusuran yang berkaitan dengan bagaimana respon masyarakat terhadap pendidikan Madrasah Diniyah Takmiliyah di Kabupaten Rejang Lebong, bagaimana manajemen Madrasah Diniyah Takmiliyah di Kabupaten Rejang Lebong, apa faktor pendukung dan faktor penghambat pelaksanaan MDT Kabupaten Rejang Lebong, serta adakah solusi bagi masyarakat menyikapi kekurangan jam belajar agama pada sekolah.

Setelah dilakukan kajian sebagai landasan teori dalam menjalankan penelitian ini, maka penelitian memakai landasan teori Fenomenologi. "Fenomenologi diartikan sebagai : 1) pengalaman subjektif atau pengalaman fenomenoloikal; 2) suatu studi tentang kesadaran dari perspektif pokok dari seseorang (Husserl)"" "Fenomenologi kadang-kadang digunakan sebagai perspektif filosofi dan juga digunakan sebagai pendekatan dalam metodologi kualitatif. Fenomenologi memiliki riwayat yang cukup panjang dalam penelitian social termasuk psikologi, sosiologi dan pekerjaan sosial. Fenomenologi merupakan pandangan berpikir yang menekankan pada focus kepada pengalaman-pengalaman subjektif manusia dan interpretasi-interpretasi dunia. Dalam hal ini, para fenomenologis ingin memahami bagaimana dunia muncul kepada orang lain."10 "Persepsi ; Fenomenologi murni hanya mendeskripsikan dunia setiap orang, namun hampir semua ahli banyak tertarik pada sumber-sumber yang tidak disadari yang mengorganisasikan kesadaran. Teori Fenomenologi terutama membagi tentang isu-isu bahasa sejauh manakah diberikan kepada peranan utama dalam membentuk

\footnotetext{
${ }^{9}$ Lexy J. Moleong, Metodologi Penelitian Kualitatif, PT. Remaja Rosdakarya, 2006, hal. 14

${ }^{10}$ Ibid. hal. 15
} 
pengalaman. Freud memandang libido sebagai dasar utama agen penyebab dalam fenomenologi perkembangan."11 "Peneliti kualitatif cenderung berorientasi fenomenologis, namun sebagian besar diantaranya tidak radikal, tetapi edalis pandangannya. Mereka member tekanan pada segi subjektif, tetapi mereka tidak perlu mendesak atau bertentangan dengan pandangan orang yang mampu menolak tindakan itu. Sebagai gambaran diberikan contoh, misalnya guru mungkin percaya bahwa ia dapat berjalan menembus dinding batu -bata, tetapi untuk mencapainya memerlukan pemikiran. Hakikatnya, batu-bata itu keras untuk ditembus, namun guru itu tidak perlu merasakan bahwa ia tidak mampu berjalan menembus dinding itu. Peneliti kualitatif menekankan berpikir subjektif karena, sebagai yang mereka lihat, dunia didominasi oleh objek yang kurang keras dibandingkan dengan batu. Manusia kurang lebih sama dengan mesin kecilyang dapat melakukan sesuatu. Kita hidup dalam imajinasi kita, lebih banyak berlatar belakang simbolik daripada kongkrit." 12

Setelah dilakukan kajian landasar teori di atas, maka peneliti berkeyakinan dengan menggunakan landasan teori Fenomenologi dalam penelitian ini akan menghasilkan sebuah penelitian dapat memberikan jawaban dari permasalahan yang yang diangkat. Dan selanjutnya setelah dilakukan kajian pustaka, peneliti belum menemukan penelitian yang sama dengan judul penelitian penulis "Respon Masyarakat Terbadap Madsarah Diniyah Takmiliyah di Kabupaten Rejang Lebong", namun ada beberapa penelitian yang ada hubungannya dengan penelitian penulis, anatara lain :

Naimah, mahasiswa program Pascasarjana UIN Sunan Kalijaga Yogjakarta,, pada tahun 2010 melakukan penelitian dengan membuat tesis yang berjudul Kebijakan Pemerintab Pekalongan Tentang Sekolab Model Pendidikan Agama Islam (Studi Implementasi di SMPN 5 Pekalongan). Penelitian ini menggunakan unsur kebijakan pemerintah dalam hal pembentukan sekolah model Pendidikan Agama Islam yang ada di Pekalongan. Hasil penelitian menunjukkan bahwa ada beberapa faktor yang melatarbelakangi lahirnya kebijakan Kota Pekalongan terkait pembentukan sekolah model Pendidikan Agama Islam, diantaranya faktor akademik, faktor sosio cultural, dan faktor politik yang dikemas dalam sebuah Peraturan Pemerintah Kota Pekalongan ${ }^{13}$.

A.Nuryadin, mahasiswa Program Pascasarjana UIN Sunan Kalijaga Yogjakarta, pada tahun 2012 melakukan penelitian dengan membuat tesis yang berjudul "Implementasi Peraturan Daerah Kabupaen Pandeglang No. 27 Tahun 2007 Tentang Wajib Belajar MadrasabDiniyah Awwaliyah di Kecamatan Cisata".

\footnotetext{
11 Ofcit, hal. 16

12 Ibid. hal. 19

${ }^{13}$ Chichi 'Aisyatud Da'watiz Zahroh, Model Madrasah Diniyah Terintegrasi pada Sekolah Dasar Negeri Sindurejan Yogjakarta, Tesis 2016, hal.8
} 
Hasil penelitian menunjukan bahwa implementasi perda ini belum dilaksanakan dengan baik karena ada hambatan yaitu kurangnya komitmen dari implementator untul melaksanakan Perda dan tidak ada sanksi bagi implementator yang tidak melaksanakan. Tetapi ada dampak positifnya yaitu guru Madsarah Diniyah Awwaliyah memiliki semangat untuk mendukung program ini dan masyarakat memiliki kepedulian tinggi terhadap perkembangan agama anak didik. ${ }^{14}$

Chicha 'Aisyatud Da'watiz Zahro, mahasiswa Program Pascasarjana UIN Sunan Kaligaja Jogyakarta pada tahun 2016 melakukan penelitian dengan membuat tesis yang berjudul " Model Madrasah Diniyah Terintegrasi Pada Sekolah Dasar Negeri Sinderejan Yogjakarta". Dari hasil penelitain menunjukkan bahwa dengan terintegrasinya pendidikan Diniyah pada Sekolah Dasar Negeri Sinderejan Yogjakarta mempunyai dampak positif karena multi manfaat antara lain, Pertama para siswa tidak direpotkan pulang dan pergi lagi ke sekolah untuk mengikuti pembelajaran pada MDT karena pelaksanaannya di Sekolah Dasar anak yang bersangkutan dan sangat dimungkinkan semua siswanya ikut semua karena pelaksanaannya sehabis jam belajar sekolah. Kedua termanfaatkannya para Penyuluh Agama Honorer $(\mathrm{PAH})$ non PNS yang diangkat oleh pihak Kemenag karena guru yang mengajar program MDT nya para PAH tersebut, sehingga pihak Sekolah Dasar tidak mengalami kesulitan mencari guru juga dalam menganggarkan honornya.

\section{Pengertian Madrasah Diniyah}

Kata "Madrasah diambil dari akar kata darasa yang berarti belajar. Madrasah adalah isim makan dari kata ini sehingga berarti tempat untuk belajar." 15 . Istilah madrasah sering diidentikkan dengan istilah sekolah atau semacam bentuk perguruan yang dijalankan oleh sekelompok atau institusi umat Islam.

Kata "Madrasah" berasal dari bahasa Arab sebagai keterangan tempat (dzaraf), dari akar kata : "Darasa, Yadrusu, Darsan, dan Madrasatan". Yang mempunyai arti "Tempat belajar para pelajar" atau diartikan "jalan" (Thariq), misalnya : diartikan : "ini jalan kenikmatan". Sedangkan kata "Midras" diartikan "buku yang dipelajari" atau "tempat belajar."16

Dalam bahasa Indonesia madrasah disebut dengan sekolah yang berarti bangunan atau lembaga untuk belajar dan memberi pengajaran. Dahulu dalam dekade sebelum tahun 2006 amat akrab dengan sebutan Madrasah Diniyah Awaliyah (MDA). Lalu dengan berkembangnya berbagai inovasi dan

\footnotetext{
${ }^{14}$ Chichi ‘Aisyatud Da'watiz Zahroh, Model Madrasah Diniyah Terintegrasi pada Sekolah Dasar Negeri Sindurejan Yogjakarta Tesis 2016, hal.8

${ }^{15}$ Sejarah Pendidikan Islam pada Priode Klasik dan Pertengahan, hal. 50

${ }^{16}$ Ibid. , hal. 50
} 
kemajuan MDA pun ingin bergerak menuju suatu kemajuan, maka berubahlah dengan sebutan Madrasah Diniyah Takmiliyah. Kata takmiliyah berartinya disempurnakan, maka sekarang pada sebutan resminya adalah Madrasah Diniyah Takmiliyah (MDT), tingkat Ula yang santrinya dari anak sekolah SD, tingkat wustha yang santrinya anak dari sekolah SMP sederajat, tingkat 'Ulya yang santrinya dari anak sekolah SMA sederajat.

Pengertian Madrasah Diniyah Takmiliyah adalah satuan pendidikan keagamaan nonformal menyelenggarakan pendidikan agama Islam yang merupakan suplemen, hingga saat ini yang baru ada dan dikelola oleh masyarakat muslim adalah tingkat dasar Madrasah Diniyah Takmiliyah Awaliyah (MDTA) dengan masa belajar 4 (empat) tahun, dan jumlah jam belajar 18 jam seminggu. Karena itu memperhatikan dari pengertian yang telah dikemukakan tersebut di atas, maka sekaligus membedakan antara Madrasah Diniyah Takmilyah dan Madrasah Ibtidaiyah sekalipun pada satu sisi terdapat kesamaan yakni sebagai pendidikan agama Islam pada tingkat dasar. Perbedaan tersebut terletak bahwa Madrasah Ibtidaiyah merupakan pendidikan formal, meliputi pelajaran agama 30\% dan umum $70 \%$ yang umumnya diselenggarakan sejak pagi (sama dengan SD). Sedangkan Madrasah Diniyah Takmiliyah merupakan pendidikan nonformal yang diselenggarakan oleh swasta atau masyarakat muslim (hasil swadaya masyarakat), hanya berisikan pelajaran agama yang umumnya diselenggarakan pada sore hari setelah selesai pendidikan di SD.

Sejarah Madrasah di Indonesia. Madrasah adalah saksi perjuangan pendidikan yang tak kenal henti. Pada jaman penjajahan Belanda Madrasah didirikan untuk semua warga. Sejarah mencatat, Madrasah pertama kali berdiri di Sumatra, Madrasah Adabiyah ( 1908, dimotori Abdullah Ahmad), tahun 1910 berdiri Madrasah Schoel di Batusangkar oleh Syaikh M. Taib Umar, kemudian M. Mahmud Yunus pada 1918 mendirikan Diniyah Schoel sebagai lanjutan dari Madrasah Schoel, Madrasah Tawalib didirikan Syeikh Abdul Karim Amrullah di Padang Panjang (1907). lalu, Madrasah Nurul Uman didirikan H. Abdul Somad di Jambi.

Karakteristik Pendidikan Diniyah Takmiliyah. Karakteristik pendidikan madrasah diniyah takmiliyah antara lain :

Pertama, Pendidikan Diniyah Takmiliyah (suplemen) yang berada di tengah masyarakat dan tidak berada dalam lingkaran pengaruh pondok pesantren. Pendidikan diniyah jenis ini betul-betul merupakan kreasi dan swadaya masyarakat, yang diperuntukkan bagi anak-anak yang menginginkan pengetahuan agama di luar jalur sekolah formal.

Kedua, pendidikan diniyah yang berada dalam lingkaran pondok pesantren tertentu, dan bahkan menjadi urat nadi kegiatan pondok pesantren. 
Ketiga, pendidikan keagamaan yang diselenggarakan sebagai pelengkap (komplemen) pada pendidikan formal di pagi hari.

Keempat, pendidikan diniyah yang diselenggarakan di luar pondok pesantren tapi diselenggarakan secara formal di pagi hari, sebagaimana layaknya sekolah formal

\section{Jenis Penelitian}

Jenis penelitian yang peneliti gunakan adalah diskriptif kualitatif. Selanjutnya metode penelitian adalah "strategi umum yang dianut dalam pengumpulan data dan analisis data yang diperlukan, guna menjawab persoalan yang dihadapi yang merupakan rencana pemecahan bagi persoalan yang sedang diselidiki,"17

Adapun metode penelitian yang akan peneliti gunakan adalah "penelitian lapangan atau fild research. Fild research adalah penelitian yang dilaksanakan di suatu tempat, di luar perpustakaan dan laboratorim" "Penelitian ini menggunakan data kualitatif tanpa adanya manipulasi, yang akan menghasilkan data deskriptif berupa kata-kata tertulis atau lisan dari orang-orang dan prilaku yang diamati." ${ }^{\prime 19}$ Penelitian lapangan dalam penelitian ini dilakukan secara langsung tentang bagaimana respon masyarakat terhadap pendidikan Madrasah Diniyah Takmiliyah di Kabupaten Rejang Lebong, bagaimana manajemen Madrasah Diniyah Takmiliyah di Kabupaten Rejang Lebong, apa faktor pendukung dan faktor penghambat pelaksanaan MDT Kabupaten Rejang Lebong, serta adakah solusi bagi masyarakat menyikapi kekurangan jam belajar agama pada sekolah.

Adapun pendekatan Penelitian yang digunakan dalam penelitian ini adalah pendekatan naturalistik. Observasi alami merupakan jenis penelitian kualitatif dengan melakukan observasi menyeluruh pada sebuah latar tertentu tanpa sedikitpun mengubahnya. Tujuan utamanya ialah untuk mengamati dan memahami prilaku seseorang atau kelompok orang dalam situasi tertentu.

Dalam melaksanakan penelitian, peneliti menggunakan antara lainnya berupa; kamera, sejumlah pertanyaan yang tidak terstruktur, dan instrument lain dalam melakukan pengumpulan data yang diperlukan. Peneliti mengamati proses respon masyarakat terhadap pendidikan Madrasah Diniyah Takmiliyah di Kabupaten Rejang Lebong, manajemen Madrasah Diniyah Takmiliyah di Kabupaten Rejang Lebong, faktor pendukung dan faktor penghambat pelaksanaan MDT Kabupaten Rejang Lebong, serta solusi bagi masyarakat menyikapi kekurangan jam belajar agama pada sekolah.

\footnotetext{
${ }^{17}$ Donald Ary, Pengantar Penelitian Dalam Pendidikan terj. Arief Furchan Cet. III, 2007, hal. 39. ${ }^{18}$ Zainal Arifin, Penelitian Pendidikan Metode Paradigma Baru, Cet. I, Bandung, 2011, hal.32 ${ }^{19}$ Ibid., hal.32.
} 
Teknik penentuan sampel sumber data dalam penelitian kualitatif, sampel sumber data dipilih menggunakan teknik purposive sampling dan snowball sampling. "Teknik purposive sampling adalah teknik pengambilan sampel sumber data dengan menjelajahi objek atau situasi sosial yang diteliti. Sedangkan teknik snowball sampling adalah teknik pengambilan sumber data yang pada awalnya sedikit menjadi besar" ${ }^{20}$

Teknik penentuan sampel sumber data penelitian ini pada awal memasuki lapangan dipilih orang yang memiliki kekuatan dan otoritas pada situasi sosial atau objek yang diteliti, sehingga mampu membuka pintu kemana saja peneliti akan melakukan pengumpulan data kepada pihak yang akan menjadi sumber data dalam penelitian ini adalah :
a. Kepala Kementerian Agama Kabupaten Rejang Lebong;
b. Kepala Bagian Kesra Pemda Kabupaten Rejang Lebong;
c. Ketua Forum Komunikasi Madrasah Diniyah Takmiliyah (FKDT)
Kabupaten Rejang Lebong;
d. Pengelola Madrasah Diniyah Takmiliyah;
e. Kepala Madrasah Diniyah Takmiliyah;
f. Guru Madrasah Diniyah Takmiliyah;
g. Orangtua Santri;
h. Manyarakat;
i. Pemerhati Pendidikan Madarasah Diniyah Takmiliyah.

\section{Teknik Pengumpulan Data}

a. Metode Observasi

Metode observasi yang digunakan adalah observasi partisipan. Observasi partisipan adalah "suatu kegiatan observasi dimana orang yang melalukan observasi terlibat atau berperan serta dalam lingkungan kehidupan orang-orang yang diamati" "21. "Observasi juga diartikan pengamatan dengan menggunakan seluruh alat indra terhadap penomena-penomena yang diselidiki" ${ }^{22}$. Pada metode observasi ini peneliti melakukan observasi terhadap seluruh 15 MDT dalam Kabupaten Rejang Lebong.

b. Metode Wawancara

Wawancara adalah "suatu bentuk komunikasi verbal semacam percakapan yang bertujuan untuk memperoleh informasi" ${ }^{23}$. Wawancara merupakan bentuk percakapan untuk memperoleh informasi dari orang yang mengetahui informasi yang kita cari. "Wawancara dilakukan secara

\footnotetext{
${ }^{20}$ Sugiyono, Metode Penelitian Pendidikan : Pendekatan Kuantitaif, Kualitatif dan R\&D, Bandung, 2008, hal. 300

${ }^{21}$ Zainal Arifin, Penelitian Pendidikan Metode Paradigma Baru, Cet. I, Bandung, 2011, hal.170

${ }^{22}$ Suharsini Arikunto, Prosedur Penelitia : Suatu Pendekatan Praktik ...hal. 128

${ }^{23}$ S. Nasution, Metode Research Penelitian Ilmiah, Jkt, 2006, hal.113
} 
mendalam adalah proses tanya jawab secara mendalam antara pewawancara dengan informan guna memproleh informasi yang lebih terprinci sesuai dengan tujuan penelitian" ${ }^{24}$. Wawancara pihak Kemenag Kabupaten Rejang Lebong, Kabag Kesra Kabupaten Rejang Lebong, Ketua FKDT Kabupaten Rejang Lebong, pengelola Madrasah Diniyah Takmiliyah 15 lembaga se Kabupaten Rejang Lebong, Kepala Madrasah Diniyah Takmiliyah se Kabupaten Rejang Lebong, para guru MDT, orangtua santri, tokoh masyarakat, serta pemerhati pendidikan Madrasah Diniyah Takmiliyah.

c. Metode Dokumentasi

Metode dokumentasi adalah "mengumpulkan data melalui bendabenda tertulis seperti buku-buku, majalah, dokumentasi, peraturanperaturan, notulen rapat dan lain-lain" ${ }^{\prime 25}$.

\section{Teknik Analisis Data}

Analisis data adalah "proses mencari dan menyusun secara sistematis data yang diperoleh dari hasil observasi, wawancara, catatan lapangan, dokumentasi dan yang lainnya dengan cara mengorganisasikan data ke dalam kategori, menjabarkan ke dalam unit-unit, melakukan sintesis, menyusun ke dalam pola, memilih mana yang penting dan yang akan dipelajari dan membuat kesimpulan sehingga mudah dipahami oleh diri sendiri maupun orang lain" ${ }^{\prime 26}$.

Analisis data dalam penelitian kualitatif ini menggunakan analisis interaktif yang terdiri dari tiga komponen pokok yaitu reduksi data, sajian data, dan penarikan kesimpulan dengan verifikasinya. Analisis data dalam penelitian kualitatif merupakan proses penyederhanaan data dalam bentuk yang mudah dibaca dan diinterpretasikan.

Adapun tahapannya adalah sebagai berikut : Pertama, dengan reduksi data, dimana reduksi data diartikan sebagai proses pemilihan, pemusatan perhatian dan penyederhanaan, pengabstrakan, dan transformasi data kasar yang muncul dari catatan-catatan dilapangan. Kedua, melalui penyajian data, penyajian disini sebagai sekumpulan informasi tersusun yang memberi beberapa kemungkinan adanya penarikan suatu kesimpulan dan untuk pengambilan tindakan. Ketiga, hal terakhir dengan menarik kesimpulan disini antara lain dengan mencatat pola-pola, tema, dan membuat sesuatu pengelompokan. Tiga alur analisis data kualitatif di atas merupakan suatu proses siklus interaktif ${ }^{\prime 27}$.

\footnotetext{
${ }^{24}$ Zainal Arifin, Penelitian Pendidikan Metode Paradigma Baru, Cet. I, Bandung, 2011, hal.170

${ }^{25}$ Cholid Nurbuko, Metode Penelitian, Jakarta, 2005, hal. 85

${ }^{26}$ Sugiyono, Metode Penelitian Pendidikan : Pendekatan Kuantitatif, kualitatif, dan R\&D, hal. 335

${ }^{27}$ Matthew B. Miles dan A, Michael Huberman, Analisis Data Kualitatif, Buku Sumber Tentang Metode-metode Baru, Jakarta 1992, 16-21
} 


\section{Pembahasan}

\section{Regulasi Penyelenggaraan Madrasah Diniyah Takmiliyah :}

1. Undang-Undang Nomor 20 tahun 2003 tentang sistem pendidikan nasional pada pasal 26 : (4) Jo pasal 30 : (4) : "satuan pendidikan nonformal terdiri atas lembaga kursus, lembaga pelatihan, kelompok belajar, pusat kegiatan belajar masyarakat, dan majelis taklim, serta satuan pendidikan yang sejenis"،28. Dan pasal 30: (4) "pendidikan keagamaan berbentuk ajaran diniyah, pesantren, pasraman, pabhaja samanera, dan bentuk lain yang sejenis" 29 .

2. Peraturan Pemerintah RI Nomor 55 tahun 2007 tentang Pendidikan Agama dan Pendidikan Keagamaan sebagaimana tertuang pada pasal 21: (1) dan (2) Jo pasal 25: (1) dan (2) : “(1) pendidikan diniyah nonformal diselenggarakan dalam bentuk pengajian kitab, majelis taklim, pendidikan Al-Quran, Diniyah Takmiliyah, atau bentuk lain yang sejenis. (2) pendidikan diniyah nonformal sebagaimana dimaksud pada ayat (1) dapat berbentuk satuan pendidikan"30. Dan pasal 25: (1), (2) :'Diniyah Takmiliyah bertujuan untuk melengkapi pendidikan agama Islam yang diperoleh di SD/MI,SMP/MTs,SMA/MA atau di pendidikan tinggi dalam rangka peningkatan keimanan dan ketakwaan peserta didik kepada Allah SWT. (2) penyelenggaraan diniyah takmiliyah dapat dilaksanakan secara berjenjang atau tidak berjenjang," ${ }^{31}$

3. Peraturan Menteri Agama RI Nomor 13 tahun 2014 tentang Pendidikan Keagamaan Islam pada pasal 20 hurup a,b,dan c sebagai berikut : "pendidikan diniyah terdiri atas: a. pendidikan diniyah formal; b. pendidikan diniyah nonformal; dan c. pendidikan diniyah informal",32.

Berdasarkan data dari Kepala Seksi Pekapontren Kemenag Kabupaten Rejang Lebong dan dikomprontir dengan Ketua FKDT Kabupaten Rejang Lebong, serta hasil investigasi peneliti yang langsung terjun ke lapangan didapati bahwa lembaga madrasah diniyah takmiliyah di Kabupaten Rejang lebong sebanyak 15 :

Dari data lembaga yang dikemukakan di atas, berdasarkan hasil survei langsung yang peneliti lakukan di lapangan, bahwa ada satu Madrasah Diniyah Takmiliyah yaitu Madrasah Diniyah Takmiliyah Miftahul Jannah di Desa Karang Jaya Kecamatan Selupu Rejang yang merupakan Diniyah pada Pondok Pesantren, dengan mengacu pada kurikulum atau mata pelajaran yang diamanahkan sebagaimana dimaksud pasal 48: (1) "kurikulum madrasah

\footnotetext{
${ }^{28}$ Departemen Agama RI tahun 2006, Undang-Undang RI Nomor 20 tabun 2003, hal.55

${ }^{29}$ Ibid. , hal. 57

${ }^{30}$ Kementerian Agama RI 2014, Regulasi Pendidikan Diniyah dan Pondok Pesantren, hal.11

${ }^{31}$ Ibid. , hal.13

${ }^{32}$ Kementerian Agama RI 2014, Regulasi Pendidikan Diniyah dan Pondok Pesantren, hal.43
} 
diniyah takmiliyah terdiri atas mata pelajaran pendidikan keagamaan Islam yang paling sedikit meliputi: a. Al-Quran; b. Al-Hadist; c. Fiqih; d. Akhlak; e. Sejarah Kebudayaan Islam; dan f. Bahasa Arab.",33

\section{Respon Masyarakat Terhadap Madrasah Diniyah Takmiliyah di Kabupaten Rejang Lebong}

Seperti dikemukakan di atas Madrasah Diniyah Takmiliyah yang ada di Kabupaten Rejang Lebong berjumlah 15 lembaga yang tersebar hanya pada beberapa kecamatan yaitu ; pada Kecamatan Curup Kota yaitu sebanyak tiga MDT yaitu PKWI di Kelurahan Pasar Tengah, Al-Ikhlas di Kelurahan Talang Benih, dan Al-Hawariy di Kelurahan Dwi Tunggal. Kecamatan Curup Selatan satu yaitu MDT Aisyiyah, Kecamatan Curup Tengah lima MDT yaitu KAT di Kelurahan Palak Siring, Al-Ukhuwah di Kelurahan Banyu Mas, ArRahmah BTN Air Bang, Al-Muhajirin di Kelurahan Batu Galing, dan Bahrul Ulum IKLB. Kecamatan Selupu Rejang dua MDT yaitu Miftahul Jannah di Desa Karang Jaya dan Al-Mustaqim di Desa Air Meles Atas. Kecamatan Curup Timur sebanyak dua MDT yaitu Al-Ikhlas di Kelurahan Kesambe Baru dan Khaoirul Walad di Desa Duku Ilir, serta di Kecamatan Bermani Ulu satu MDT yaitu Al-Hadid di Desa Kampung Melayu.

Memperhatikan dari segi jumlah satuan pendidikan MDT, berikut dengan wilayah dimana satuan pendidikan diselenggarakan, bila dibandingkan dengan luas wilayah dengan jumlah desa dan kecamatan yang ada belum sebanding upaya pemerintah merumuskan dan membuat payung hukum sebagai regulasi dalam memberikan sebuah perlindungan yang sekaligus melahirkan sebuah pengakuan terhadap satuan pendidikan yang dikelola oleh masyarakat muslim dalam bentuk satuan pendidikan nonformal yang merupakan respon dan jawaban pemerintah terhadap desakan dari berbagai pihak pada beberapa decade lalu, karena kuranynya jam belajar agama pada sekolah, maka salah satu indikator yang menunjukkan bahwa rendahnya respon masyarakat muslim terhadap keberadaan MDT. Hal senada sebagaimana juga dikemukakan oleh Tegu Ati, S.Ag, M.Pd (Kepala Seksi Pekapontren) Kemenag Kabupaten Rejang Lebong bahwa " para orangtua yang memiliki anak dan cucu terutama pada usia sekolah dasar kurang memiliki hasrat dan perhatian untuk menyerahkan anak dan atau cucunya untuk didik pada Madrasah Diniyah Takmiliyah (MDT) yang telah ada baik berada pada sekitar tempat tinggal yang bersangkutan maupun yang agak jauh, walau ada yang perduli dan memiliki hasrat untuk itu jumlahnya sangat sedikit" ${ }^{\prime 34}$ Tidak jauh berbeda juga dengan yang diungkapkan oleh Zetti Sarliana, S.Sos.I (Kepala MDT Ar-Rahmah sekaligus Ketua FKDT

\footnotetext{
${ }^{33}$ Kementerian Agama RI 2014, Regulasi Pendidikan Diniyah dan Pondok Pesantren, hal. 57

${ }^{34}$ Wawancara pada tanggal 19 Juli 2017
} 
Kabupaten Rejang Lebong) bahwa "sangat rendah sekali respon mayoritas orangtua yang memiliki anak dan atau cucu terhadap keberadaan MDT untuk menyerahkan anak dan atau cucunya belajar pada lembaga dimaksud, bebeda halnya dalam memberikan bekal ilmu pengetahuan umum umpamanya belajar Matematika, Bahasa Inggris, maupun pelajaran umum lainnya dan tidak merasa keberatan bila harus mengeluarkan dana untuk itu walaupun nominalnya jauh lebih besar dari nominal yang dikeluarkan untuk belajar pada MDT, dan bahkan terkadang yang telah masuk dan belajar pada MDT lalu diminta atau diumumkan yang belum membayar spp, maka terkadang besoknya sebagian anak atau santri tersebut tidak mau masuk dan datang lagi atau berhenti untuk belajar. Setelah itu didapati info karena dimintai membayar spp bulanan yang sudah lama nunggak" ${ }^{35}$ Ungkapan senada juga seperti yang diungkapkan oleh Niti Hartati, S.Pd (wakil kepala MDT Aisyiah) Tempel Rejo yang sekaligus juga guru bahwa "rendahnya kesadaran orangtua untuk menyerahkan pendidikan anak dan atau cucunya di MDT dan kalaupun telah masuk pada MDT apabila seandainya dipinta untuk membayar SPP, sering sekali akhirnya anak tersebut tidak disuruh lagi melanjutkan belajar alias berhenti oleh orantuanya",36

Rendahnya respon dan kesadaran tersebut diantara lainnya :

1. Masih kurangnya perhatian pemerintah pusat dalam hal ini pihak Kementerian Agama dan Pemerintah Daerah. Karena itu idealnya pihak Kementerian Agama dan Pemerintah Daerah bersinergi dalam memberikan suport kucuran dana berupa umpama dana ; Biaya Operasional Pendidikan (BOP), insentif guru, bantuan pembanguan gedung baik lokal belajar maupun gedung kantor, dan kebutuhan lainnya, hal tersebut sesuai dengan yang diamanahkan oleh Peraturan Pemerintah RI nomor 48 tahun 2008 pasal $2: 1$ dan 2 "(1) Pendanaan pendidikan menjadi tanggung jawab bersama antara Pemerintah, pemerintah daerah, dan masyarakat. (2) Masyarakat sebagaimana dimaksud pada ayat (1) meliputi : a. penyelenggara atau satuan pendidikan yang didirikan masyarakat; b. peserta didik, orang tua atau wali peserta didik; dan c. pihak lain selain yang dimaksud dalam huruf a dan huruf $b$ yang mempunyai perhatian dan peranan dalam bidang pendidikan"37. Dari Peraturan Pemerintah nomor 48 tahun 2008 tersebut, maka dapat dipahami bahwa tanggung jawab pendanaan penyelenggaraan satuan pendidikan adalah tanggung jawab bersama, mulai pemerintah pusat, pemerintah daerah dan masyarakat itu sendiri baik secara langsung yang berkepentingan maupun

\footnotetext{
${ }^{35}$ Wawancara pada tanggal 20 Juli 2017

${ }^{36}$ Wawancara pada tanggal 03 Agustus 2017

${ }^{37}$ Departemen Pendidikan Nasional, Peraturan Pemerintah Nomor 48 tabun 2008 tentang Pendanaan Pendidikan, 2008 hal. 2
} 
yang terkait langsung dengan kepentingan pendidikan dimaksud. Sementara itu kondisi pendanaan MDTA mulai dari para pengelola, para guru, para orangtua murid/santri belum mampu untuk mengangkat bersama pendanaan tersebut, sehingga sangat dibutuhkan perhatian yang nyata dari pemerintah, maupun pemerintah daerah dalam bentuk kucuran pendanaan yang memadai. Sehingga dengan adanya perhatian seperti demikian, maka penulis mempunyai keyakinan para pengelola dan para guru akan semakin bersemangat dan masyarakat akan semakin banyak yang tertarik untuk membuka lembaga MDT baru yang sekaligus berimbas pada penyerapan tenaga kerja baik untuk sebagai tenaga kependidikan maupun tenaga pendidik. Seperti halnya kebijakan Gubernur DKI yang mengeluarkan Peraturan Gubernur Provinsi Daerah Khusus Ibukota Jakarta Nomor : 168 tahun 2007, Tentang : Pemberiana Bantuan Bagi Guru Bantu, Guru Madrasah Diniyah, Siswa Madrasah Ibtidaiyah, Tsanawiyah, SD dan SMP Swasta di Lingkungan Provinsi Daerah Khusus Ibukota Jakarta. Pada pasal 2 ayat (1) dan (2) memuat tujuan bantuan dan sasaran bantuan : “(1) Tujuan pemberian bantuan adalah a. upaya pemerataan dan perluasan akses, peningkatan mutu, relevansi dan daya saing serta penguatan tata kelola, akuntabilitas dan pencitraan public pada satuan pendidikan SD Swasta/MI Swasta, SMP Swasta/MTs Swasta di Provinsi DKI Jakarta; b. Upaya peningkatan kinerja para guru bantu dan guru Diniyah di Provinsi DKI Jakarta. (2) Sasaran penerima bantuan adalah a. Guru Bantu, b. Guru Madrasah Diniyah, c. SD Swasta dan MI Swasta, d. SMP Swasta dan MTs. Swasta" ${ }^{\text {} 38}$. Sementara besaran bantuan sebagaimana tercantum pada pasal yang berbunyi : "(1) Besaran bantuan yang diberikan kepada penerima bantuan adalah sebagai berikut. a. Guru Bantu sebesar Rp. 500,000 (lima ratus ribu rupiah) / orang/bulan. b. Guru Madrasah Diniyah sebesar Rp.500.000 (lima ratus ribu rupiah)/orang/bulan, c. SD Swasta dan MI Swasta berdasarkan jumlah siswa, dialokasikan seluruhnya sebesar Rp.12.729.644.333,00 (dua belas miliar tujuh ratus dua puluh Sembilan juta enam ratus empat puluh empat ribu tiga ratus tiga puluh tiga rupiah). d. SMP Swasta dan MTs Swasta berdasarkan jumlah siswa, dialokasikan seluruhnya sebesar Rp.19.197.824.000,00 (Sembilan belas miliar seratus Sembilan puluh tujuh juta delapan ratus dua puluh empat ribu rupiah)"39. Memperhatikan dari Peraturan Gubernur tersebut menunjukan bahwa perhatian yang diberikan oleh Gubernur tersebut memberikan dampak yang positif akan timbulnya semangat yang membawa kepada meningkatnya etos kerja yang

\footnotetext{
${ }^{38}$ Peraturan Gubernur Provinsi Daerah Khusus Ibukota Jakarta Nomor 168 tahun 2007 ${ }^{39} \mathrm{Ibid}$.
} 
berujung pada peningkatak kualitas proses pembelajaran, dan bila proses pembelajaran meningkat kualitasnya, maka akan menghasilkan out put yang berkualitas pula. Sementara itu kebijakan Pemerintah Kabupaten Rejang Lebong telah melakukan hal serupa namun belum begitu sangat dirasakan oleh masyarakat secara keseluruhan seperti yang dikemukakan oleh Jamaan Nur, S.Ag, M.Pd (Kabag Kesra) Kabupaten Rejang Lebong bahwa : "Dalam upaya untuk mewujudkan masyarakat Rejang Lebong yang religious telah ditempatkan sarjana agama untuk memberikan pendidikan agama pada masyarakat desa sebanyak 52 desa yang berada pada wilayah Kecamatan Binduriang yang pada masing-masing desa tersebut ditempatkan satu orang petugas" ${ }^{\text {"40 }}$. Senada dengan hal tersebut sebagian kecil guru Madrasah Diniyah Takmiliyah ada juga yang mendapat insentif yang bersipat tidak permanen dan tidak merata. Seperti yang dikemukakan oleh Tegu Ati, S.Ag, M.Pd (Kepala Seksi Pekapontren Kemenag Rejang Lebong) bahwa : "sebagian kecil guru Madrasah Diniyah Takmiliyah ada yang mendapatkan insentif yang sumber dananya dari BAZNAS kabupaten Rejang Lebong yang diterima 3 bulan sekali sebagai program pendistribusian zakat dari BAZNAS sisi konsumtif yang besarannya Rp. 250.000 ,/bulan" ${ }^{\text {"41. }}$. Hal senada seperi yang diungkapkan oleh Susmaningsih (Kepala MDT Al-Ukhuwah) bahwa : "Guru pada MDAnya pernah mendapat insentif dari Pemda Rejang Lebong melalui Kabag Kesra dibayar dalam 3 bulan sekali sejumlah Rp.450.000, dan juga mendapat insentif dari BAZNAS Kabupaten Rejang Lebong dengan besaran Rp.250.000 perbulan dibayar 3 bulan sekali kedua sumber dana tersebut tidak bersifat permanen dan tidak semua guru-guru kami mendapat serta tidak setiap tahunnya" ${ }^{42}$;

2. Masih belum tersosialisasinya dengan baik dan maksimal tentang eksistensi MDT dengan regulasi yang ada dan cukup kuat, bagi masyarakat muslim lebih khusus orangtua yang memilki anak dan atau cucu pada usia sekolah paling tidak usia SD dan SLTP. Indikasi dari itu sebagian pengelola MDT maupun sebagian guru masih belum sepenuhnya mengetahui dan memahami akan eksistensi MDT tersebut sebagai pendidikan suplemen, penambah kekurangan jam belajar agama pada sekolah. Mereka bekerja menjalankan pengelolaan MDT dan mengajar tersebut berdasarkan kebiasaan alami saja dan mengisi waktu daripada nganggur. Apalagi kondisi sekarang ini dimana-mana sudah sulit untuk mencari honor sebagai guru mengajar pada lembaga satuan pendidikan

\footnotetext{
${ }^{40}$ Wawancara pada tanggal 01 Agustus 2017

${ }^{41}$ Wawancara pada tanggal 19 Juli 2017

${ }^{42}$ Wawancara pada tanggal 03 Agustus 2017
} 
apalagi yang negeri, karena nyaris sudah penuh semua dan tidak membutuhkan tenaga guru honorer terutama di Kabupaten Rejang Lebong;

3. Kurang menariknya tampilan manajemen pengelolaan MDT terutama sarana dan prasarana yang tersedia dan belum banyak diketahui oleh masyarakat akan muatan kurikulumnya. Kekurang menariknya tampilan dengan sangat minimnya sarana dan prasarana dan belum diketahuinya muatan kurikulumnya salah satu dari banyak penyebab kurang diminati. Menjadi suatu kenyataan yang tidak dapat dipungkiri bahwa bagaimana satuan pendidikan yang dikelola oleh yang menamakan diri sebagai satuan pendidikan "Islam Terpadu" tingkat apapun juga seperti contoh Sekolah Dasar Islam Terpadu (SDIT), Sekolah Menengah Pertama (SMPIT) walaupun mereka dengan biaya SPP nya mahal tetapi keyakinan masyarakat kuat lalu mereka berduyun-duyun untuk memasukkan anaknya sekolah pada lembaga tersebut, sehingga lembaga satuan pendidikan sempat kewalahan untuk menampungnya, lalu dilakukan testing secara ketat. Karena itu bagaimana agar MDT mampu menciptakan kondisi dua hal yang sangat urgen (penting) tersebut. Sehingga ketertarikan dan beriring dengan keyakinan dengan beban kurikulum yang ada satuan pendidikan MDT tersebut mampu bersaing outputnya lembaga Islam Terpadu (IT) tersebut;

4. Belum adanya regulasi yang bersifat mengikat baik dari Pemerintah Pusat maupun Pemerintah Daerah. Untuk menciptakan hal demikian diperlukan adanya perhatian pemerintah paling tidak Pemerintah Daerah, seperti yang dapat kita lihat di Kabupaten Indramayu dimana jumlah lembaga MDT nya mencapai ribuan setelah dilahirkannya Peraturan Daerah (PERDA) Kabupaten Indramayu nomor : 12 tahun 2012 tentang : Wajib Belajar Diniyah Takmiliyah. Dari Perda tersebut didapati pasal yang antara lainnya memberikan posisi dan eksistensi madrasah diniyah sebagaimana diungkapkan pada pasal 2 sampai pasal 4 yang berbunyi : "Pasal 2 Diniyah Takmiliyah berkedudukan sebagai satuan pendidikan agama nonformal yang menyelenggarakan pendidikan agama sebagai penyempurna pengajaran pendidikan agama pada setiap jenjang pendidikan. Pasal 3 Wajib belajar Diniyah Takmiliyah berfungsi untuk memenuhi kebutuhan pendidikan agama bagi peserta didik yang belajar di setiap jenjang pendidikan. Pasal 4 Wajib belajar Diniyah Takmiliah bertujuan untuk terbentuknya peserta didik yang memahami dan mengamalkan nilai-nilai ajaran agamanya dan / atau menjadi ahli ilmu agama yang berwawasan luas, kritis, kreatif, inovatif, dan dinamis dalam rangka mencerdaskan 
kehidupan bangsa yang beriman . bertakwa, dan berakhlak mulia"43. Dan pada pasal 8 "kegiatan belajar mengajar Diniyah Takmiliyah dilaksanakan pada sore hari atau diluar jam pendidikan formal bertempat di pondok pesantren, Gedung Mandiri, Gedung Sekolah, Masjid, Musholla atau tempat lainnya yang layak" ${ }^{44}$

5. Dari beberapa pasal Perda yang telah dikemukakan di atas menjukkan bahwa Madrasah Diniyah Takmiliyah mendapatkan perhatian yang besar, diberi kedudukan dan amanah yang besar, dan tidak mencabut akar pola penyelenggaraan yang tetap diselenggarakan oleh masyarakat. Namun dampak dari Perda tersebut, maka bermunculan madrasah Diniyah Takmiliyah yang baru sehingga angka jumlah lembaganya mencapai lebih dari 1000 an lembaga. Yang demikian pasti memberikan dampak yang sangat positif baik pada perkembangan dalam rangka pembentukan akhlak terhadapat anak-anak, maupun dalam upaya menciptakan kader-kader intelektual agama Islam yang imbrionya dari pendidikan Diniyah Takmiliyah. agar dengan pendidikan diniyah takmiliyah diharapkan mampu menciptakan masyarakat yang berakhlak mulia oleh pemerintah daerah Kabupaten Indramayu. Penulis berkeyakinan jika seandainya pemerintah Daerah Kabupaten Rejang Lebong melahirkan Perda serupa paling tidak, maka lembaga Diniyah Takmiliyah yang ada akan semakin eksis dan akan bermunculan Madrasah Diniyah Takmiliyah yang baru karena adanya regulasi tekanan yang mengikat.

\section{Manajemen Penyelenggaraan Madrasah Diniyah Takmiliyah}

Dari 15 madarasah diniyah takmiliyah di Kabupaten Rejang Lebong manajemen penyelenggaraannya cukup bervariasi. Ada yang penyelenggaraannya di bawah naungan sebuah yayasan, ada yang di bawah sebuah yayasan yang dapat dikatakan semu, ada yang terpisah antara kepala dengan guru, dan ada yang kepala merangkap juga sebagai guru. Jika ingin melihat pola manajemen penyelenggaraannya, maka dapat kita lihat melalui data berikut:

\begin{tabular}{|c|c|c|c|}
\hline $\mathrm{NO}$ & MDTA & POLA MANAJEMEN PENYELENGGARAAN & KEPALA \\
\hline 01 & KAT & $\begin{array}{l}\text { Dikelola sediri dimana kepala juga } \\
\text { merangkap sebagai guru namun mendapat } \\
\text { dukungan kuat dari organisasi asal daerah } \\
\text { sebagai perantau }\end{array}$ & $\begin{array}{l}\text { Drs. Syukur } \\
\text { Hamidi }\end{array}$ \\
\hline 02 & PKWI & $\begin{array}{l}\text { Dikelola sediri dimana kepala juga } \\
\text { merangkap sebagai guru namun mendapat }\end{array}$ & $\begin{array}{l}\text { May } \\
\text { Saelendra,S.P }\end{array}$ \\
\hline
\end{tabular}

\footnotetext{
43Peraturan Daerah Kabupaten Indramayu Nomor 12 tahun 2012 tentang Wajib Belajar Diniyah Takmiliah. hal.5

${ }^{44}$ Ibid hal. 5.
} 


\begin{tabular}{|c|c|c|c|}
\hline & & $\begin{array}{l}\text { dukungan kuat dari organisasi asal daerah } \\
\text { sebagai perantau }\end{array}$ & d.I \\
\hline 03 & $\begin{array}{l}\text { Baitul } \\
\text { Makmur }\end{array}$ & $\begin{array}{l}\text { Dikelola di bawah naungan yayasan Islamic Centre Baitul Makmur } \\
\text { Curup, Kepala juga merangkap sebagai guru }\end{array}$ & Yuli Wahyudi,S.Pd.I \\
\hline 04 & $\begin{array}{l}\text { Al- } \\
\text { Ukhuwah }\end{array}$ & $\begin{array}{l}\text { Dibawah naungan pengurus masjid Kelurahan Banyumas, Kepala } \\
\text { berfungsi sebagai kepala dan tidak merangkap sebagai guru }\end{array}$ & Susmaningsih \\
\hline 05 & Ar-Rahmah & $\begin{array}{l}\text { Dibawah naungan pengurus masjid Kelurahan Air Bang, Kepala } \\
\text { berfungsi sebagai kepala dan tidak merangkap sebagai guru }\end{array}$ & Zetti Sartina,S,Sos.I \\
\hline 06 & Al-Ikhlas & $\begin{array}{l}\text { Dibawah naungan pengurus musholla Kelurahan Talang Benih, } \\
\text { Kepala merangkap sebagai guru }\end{array}$ & Candra W J,S.Pd.I \\
\hline 07 & Aisyiyah & $\begin{array}{l}\text { Dibawah naungan pengurus Muhammadiyah Ranting Kelurahan } \\
\text { Tempel Rejo, Kepala merangkap sebagai guru }\end{array}$ & Alwa Suparti,S.Ag \\
\hline 08 & Al-Hadid & Berdiri dan berjalan sendiri Kepala merangkap sebagai guru & Nur Hamid \\
\hline 09 & $\begin{array}{l}\text { Al- } \\
\text { Muhajirin }\end{array}$ & $\begin{array}{l}\text { Dibawah naungan pengurus masjid Al-Muhajirin Kelurahan Batu } \\
\text { Galing, Kepala berfungsi sebagai kepala dan tidak merangkap } \\
\text { sebagai guru }\end{array}$ & Joni Anjerian,S.Ag \\
\hline 10 & $\begin{array}{l}\text { Miftahul } \\
\text { Jannah }\end{array}$ & $\begin{array}{l}\text { Dibawah naungan pengurus Yayasan Pondok Pesantren Miftahul } \\
\text { Jannah Desa Karang Jaya, Kepala berfungsi sebagai pimpinan } \\
\text { pondok pesantren dan tidak merangkap sebagai guru }\end{array}$ & M.Mandu, S.Pd.I \\
\hline 11 & $\begin{array}{l}\text { Al- } \\
\text { Mustaqim }\end{array}$ & $\begin{array}{l}\text { Dibawah naungan pengurus masjid Mustaqim, Kepala merangkap } \\
\text { sebagai guru }\end{array}$ & Purgianti,S.Pd \\
\hline 12 & Al-Ikhlas & Berdiri dan berjalan sendiri, Kepala merangkap sebagai guru & $\begin{array}{l}\text { Dona Damiyanti, } \\
\text { S.Pd.I }\end{array}$ \\
\hline 13 & $\begin{array}{l}\text { Bahrul } \\
\text { Ulum IKLB }\end{array}$ & $\begin{array}{l}\text { Dibawah naungan semu yayasan, Kepala berfungsi sebagai kepala } \\
\text { dan merangkap sebagai guru }\end{array}$ & $\begin{array}{l}\text { Tentiyo Suharto, } \\
\text { M.HI }\end{array}$ \\
\hline 14 & Al-Hawariy & $\begin{array}{l}\text { Dibawah naungan pengurus Yayasan Pondok Pesantren Al- } \\
\text { Hawariy Kelurahan Dwi Tunggal, Kepala berfungsi sebagai } \\
\text { pimpinan pondok pesantren dan tidak merangkap sebagai guru }\end{array}$ & $\begin{array}{l}\text { Hafiz Nur Iman, } \\
\text { S.Hut }\end{array}$ \\
\hline 15 & $\begin{array}{l}\text { Khaorul } \\
\text { Walad }\end{array}$ & $\begin{array}{l}\text { Dibawah naungan pengurus yayasan Yatim piatu, Kepala } \\
\text { merangkap sebagai guru }\end{array}$ & Santi \\
\hline
\end{tabular}

Dari data di atas didapati sebuah gambaran yang jelas bahwa manajemen Madrasah Diniyah Takmiliyah pengelolaannya sangat sederhana bervariasi sesuai dengan kemampuan penelolanya baik dari sisi pendanaan, dukungan dari berbagai pihak baik yang terkait secara langsung maupun dalam bentuk keperdulian dari pihak-pihak tertentu, termasuk kemampuan pengelola dalam mengembangkan dan menggaet pihak-pihak lain.

Mengingat menyangkut manajemen dalam sebuah organisasi apalagi satuan pendidikan seperti Madrasah Diniyah Takmiliyah di Kabupaten Rejang Lebong ini sangat menentukan keberlangsungan satuan pendidikan tersebut, sehingga apabila rendahnya apalagi tidak adanya dukungan dari pihak-pihak terkait bahkan tidak adanya keperdulian, maka satuan pendidikan tersebut dapat dipastikan sulit untuk mampu bertahan apalagi meningkat lebih maju. Karena itu apabila motivasi pengelola tersebut rendah dan apalagi orientasinya ingin mendapatkan pendapatan sejumlah uang, maka dapat dipastikan satuan pendidikan itu tidak akan bertahan lama. Akan tetapi yang 
penulis dapati dari hasil survey dan wawancara langsung di lapangan ternyata pengelola Madrasah Diniyah Takmiliyah se Kabupaten Rejang Lebong tidak ada satupun yang memotivasiinya untuk mendapatkan sejumlah uang, malah uang dikantong banyak diabdikan untuk kemajuan satuan pendidikan. Seperti yang dikemukakan oleh Drs. Syukur Hamidi Kepala MDT KAT yang terletak di Kelurahan Kepala Siring Kecamatan Curup Tengah" mulai berdiri tahun 1987 hingga sekarang segala hiruk-pikuk kesulitan dalam berbagai hal nyaris diatasi dengan senantiasa mengedepankan pengabdian dan ada sama sekali memotivasiinya karena mendapatkan sejumlah keuntungan" ${ }^{45}$ Senada hal tersebut seperti yang dikemukakan oleh May Saelendra, S.Pd.I Kepala MDT FKWI yang terletak di Kelurahan Pasar Tengah Kecamatan Curup, bahwa " sejak berdiri tahun 1988 hingga sekarang tidak ada dimotivasii oleh akan mendapatkan sejumlah uang malah justeru terkadang uang pribadi sering dipakai untuk keperluan MDT $^{\text {46 }}$ ungkapan tersebut seperti halnya juga diungkapkan olek Nur Hamid Kepala MDT Al-Hadid di Desa Kampung Melayu Kecamatan Bermani Ulu "MDT berdiri tahun 2005 hingga sekarang belum ada sama sekali bekerja dan mengelola MDT karena mendapatkan sejumlah uang, malah terkadang uang pribadi sekali-sekali dipakai untuk MDT" ${ }^{47}$. Demikian juga nyaris tidak ada bedanya seperti yang diungkapkan oleh Zetti Sarliana, S.Sos.I Kepala MDT Ar-Rahmah yang juga sebagai Ketua Forum Komunikasi Diniyah Takmiliyah (FKDT) Kabupaten Rejang Lebong berdiri tahun 2002 walaupun beliau mengatakan dirinya bukan pendiri pertama yang berlokasi di Kelurahan Air Bang Kecamatan Curup Tengah beliau mengungkapkan "mengelola MDT perlu kesabaran, keuletan, keikhlasan, dedikasi yang tinggi, serta pengabdian. Karena tidak banyak yang perduli apalagi mau mengabdikan diri karena secara materi nyaris pasti tidak akan didapati walau dirinya juga mengaku terkadang mendapat juga sekalisekali ketika ada terkumpul dana dari SPP anak santrinya tetapi yang pasti tidak dapat setiap bulan dan jumlahnya pun tidak pasti terkadang mendapat Rp.100.000,- dan terkadang kurang dari itu. Namun bagi dirinya dan temanteman sesama mengajar pada MDT Ar-Rahmah cukup ada perhatian dari tokoh masyakarat dan tokoh agama dalam hal mempasilitasi tempat belajar sekarang sedang dibangun 1 unit bangunan permanen berbentuk leter L dengan ukuran $30 \mathrm{M}$ x $10 \mathrm{M}$ yang akan diperuntukkan untuk kantor dan ruang belajar MDT sehingga tidak lagi memanfaatkan ruangan lantai 2 masjid Al-Muhajirin" "48. Untuk melihat pola manajemen pengelolaan MDT di

\footnotetext{
${ }^{45}$ Wawancara pada tanggal 01 Agustus 2017

${ }^{46}$ Wawancara pada tanggal 01 Agustus 2017

${ }^{47}$ Wawancara pada tanggal 14 Agustus 2017

${ }^{48}$ Wawancara pada tanggal 20 Juli 2017
} 
Kabupaten Rejang Lebong sebagaimana dapat dilihat melalui sebagian pada bagan Struktur MDT sebagaimana pada lembaran lampiran:

Dengan memperhatikan struktur pada lampiran struktur pada sebagian MDT, maka dapat dilihat bahwa manajemen pengelolaan Madrasah Diniyah Takmiliyah (MDT) di Kabupaten Rejang Lebong kebanyakan pengelolaannya dikelola secara sangat sederhana yang cenderung dapat dikatakatagorikan masih tradisional walaupun ada sebagian kecil telah mengarah kepada manajemen yang memberikan fungsi-fungsi dan wewenang serta pembagian tugas yang jelas dan tidak tumpang tindih, itu pun baru mengarah saja, belum terkondisikan diberlakukan penuh. Hal ini menurut penjelasan dari nyaris semua pengelola MDT karena sulitnya mendapatkan personil baik pengelola, tenaga kependidikan, maupun tenaga pendidik karena bekerjanya kebanyak pengabdian yang mengharap ridho Allah SWT. Mencari orang yang mau bekerja dan mengabdi seperti itu sulit didapati. Sehingga banyak tugas rangkap seperti; dia sebagai kepala MDT juga merangkap sebagai guru, sebagai bendahara, dan lainnya, begitu juga sebaliknya. Kondisi seperti ini bertahun-tahun, berkelanjutan, serta sulit untuk terciptanya manajemen yang tidak terjadi tugas rangkap alias tumpang tindih, bahkan apabila menerapkan manajemen seidealnya, maka diyakini lembaga MDT akan mandek, sulit berjalan, bahkan bisa jadi bubar.

Selanjutnya mengenai sarana dan prasarana pengelola MDT mayoritas memafaatkan sarana dan prasarana seadanya, pendanaan seadanya, uang lelah atau gaji para guru sangat jauh dari standar kewajaran bahkan ada guru yang tidak mendapat gaji bertahun-tahun. Sehingga dapat dikatakan pengelolaannya masih sangat memprihatinkan. Yang mungkin menjadi pertanyaan kanapa bisa dan sanggup bertahan sebegitu lama baik pengelola MDTA maupun para gurunya ? hal ini disebabkan rata-rata dimotivasii oleh dua hal yang sangat penting yaitu ; motivasi ibadah dan keikhlasan.

\section{Faktor Pendukung dan Faktor Penghambat Penyelenggaraan MDTA di Kabupaten Rejang Lebong}

Berbicara faktor pendukung penyelenggaraan MDT di Kabupaten Rejang Lebong antara lain :

1. Mayoritas penduduk di Kabupaten Rejang Lebong adalah muslim;

2. Bupati dan Wakil Bupati Rejang Lebong telah sepakat mengusung salah satu visinya "menciptakan masyarakat Kabupaten Rejang Lebong yang religius;

3. Potensi calon guru cukup banyak yang merupakan alumni STAIN Curup dan juga alumni perguruan tinggi lainnya.

Sedangkan faktor penghambat penyelenggaraan MDT di Kabupaten Rejang Lebong antara lainnya : 
1. Masih rendahnya kesadaran masyarakat muslim yang memiliki anak dan atau cucu untuk menyekolahkan anaknya pada Madrasah Diniyah Takmiliyah;

2. Masih rendahnya keperdulian masyarakat muslim terhadap keberadaan MDT berimbas pada sedikitnya masyarakat yang tertarik untuk mendirikan MDT;

3. Sulitnya mendapatkan dana dalam pengelolaan MDT baik yang bersumber dari SPP santri maupun donator dari sumber pihak manapun juga.

Solusi bagi masyarakat menyikapi kekurangan jam belajar agama pada sekolah.

Jika berbicara masalah solusi dari kekurangan jam belajar agama pada sekolah untuk di sebagian besar masyarakat di Kabupaten Rejang Lebong nyaris tidak begitu pekah dengan hal tersebut, karena sesungguhnya bagi masyarakat yang merasa butuh akan pendidikan agama bagi anaknya mereka telah mencari solusi dengan memilih menyekolahkan anaknya pada antara lain :

1. Pondok Pesantren yang cendrungnya di luar wailayah Kabupaten Rejang Lebong seperti di Payakumbuh Sumatera Barat, Putri Diniyah Padang Panjang Sumatera Barat, beberapa Pondok Pesantren di Palembang Sumatera Selatan, serta beberapa Pondok pesantren di Jawa Timur;

2. Lembaga satuan pendidikan yang bercikhaskan agama Islam. Seperti Madrasah Ibtidaiyah (MI), Sekolah Dasar Islam Terpadu (SDIT) atau sejenisnya;

3. Menyekolahkan anak dan atau cucunya ke MDT walau jauh dari tempat tinggal yang bersangkutan, jumlah kelompok ini sangat sedikit sekali;

4. Mengajari sendiri anak-anak mereka di rumah, jumlah ini sangat sedikit sekali.

Empat solusi yang dilakukan oleh masyarakat muslim tersebut sesuai dengan apa yang diungkapkan oleh Drs. H. Damanhuri (Tokoh masyarakat dan sekaligus pemerhati pendidikan agama) beliau mengatakan bahwa :

"Keperdulian, kepekaan terhadap kurangnya jam belajar agama bagi orangtua yang memilki anak dan atau cucu mayoritas tidak terlalu memikirkannya. Bagi orangtua yang perduli terhadap pembekalan agama terhadap anaknya mereka jauh-jauh hari telah memprogram untuk menyekolahkan pada beberapa lembaga antara lain ; Pondok Pesantren, Madrasah Ibtidaiyah, Sekolah Dasar Islam Terpadu (SDIT) atau yang sejenis, sisanya menyekolahkan anaknya pada MDT walau tidak berada dekat tinggal mereka (jumlah ini sangat sedikit), dan terakhir mereka mengajari anak mereka sendiri di rumah (jumlah ini sangat sedikit sekali) karena alasan mereka sibuk dengan kegiatan keseharian, dan sangat jarang terdengar kalau orantua memanggil guru mengaji ke rumah untuk mengajari anak dan atau 
cucunya" "49. Hal senada juga diungkapkan oleh Drs. Zulkifli (tokoh masyarakat sekaligus pemerhati pendidikan Madrasah Diniyah Takmiliyah) bahwa : "Kepekaan dan keperdulian orangtua yang memiliki anak dan atau cucu untuk menyekolahkan di MDT sangat rendah, karena lembaga pendidikan MDT ini hanyalah dapat dikatakan hanya sebagai mengisi waktu dan bahkan sekedar sekedarnya saja indikasi dari itu tidak sedikit karena anaknya ditagih SPP lalu besaoknya tidak datang-datang lagi alias berhenti. Bagi orangtua yang peka dan merasa butuh pembekalan ilmu agama terhadap anak mereka, sekolahkan anaknya ke pondok pesantren ada yang ke Jawa Timur, Sumatera Barat, dan Sumatera Selatan, dan lainnya",50

\section{Penutup}

\section{Simpulan}

1. Rendah respon dari masyarakat terhadap pendidikan Madrasah Diniyah Takmiliyah di Kabupaten Rejang Lebong karena belum maksimalnya sosialisasi eksistensi Madrasah Diniyah Takmiliyah, kurang menariknya tampilan secara kelembagaan mengakibatkan terasa kurang meyakini kualitas output nya nanti, serta belum adanya regulasi yang bersifat mengikat untuk menyekolahkan pada lembaga Diniyah Takmiliyah dimaksud;

2. Manajemen Madrasah Diniyah Takmiliyah di Kabupaten Rejang Lebong kebanyakan masih sangat sederhana dan cendrung tradisional;

3. Faktor pendukung penyelenggaraan MDT adalah mayoritas penduduk di Kabupaten Rejang Lebong muslim, Bupati dan Wakil Bupati Rejang Lebong telah mengusung salah satu visinya "menciptakan masyarakat Kabupaten Rejang Lebong yang religius, potensi calon guru cukup banyak. Sedangkan faktor penghambat masih rendahnya kesadaran masyarakat muslim yang memiliki anak dan atau cucu untuk menyekolahkan anaknya pada Madrasah Diniyah Takmiliyah, masih rendahnya keperdulian masyarakat muslim terhadap keberadaan MDT berimbas pada sedikitnya masyarakat yang tertarik untuk mendirikan MDT, serta sulitnya mendapatkan dana dalam mengelola MDT.

4. Solusi bagi masyarakat dalam menyikapi kekurangan jam belajar agama pada sekolah adalah sebagian kecil menyekolahkan anak dan atau cucunya ke MDT walau jauh dari tempat tinggal yang bersangkutan, dan sebagian kecil mengajari sendiri anak-anak mereka di rumah, serta mayoritas orangtua apatis cendrung menerima saja out put dari pembelajaran yang ada di sekolah dengan tidak berupaya untuk memberikan tambahan belajar di luar dari sekolah.

\footnotetext{
${ }^{49}$ Wawancara pada tanggal 01 Agustus 2017

${ }^{50}$ Wawancara pada tanggal 20 Juli 2017
} 


\section{Saran-Saran}

1. Kepada pengelola MDT agar meningkatkan kualitas manajemen pengelolaan MDT dengan mengupayakan prioritas peningkatan sarana dan prasana;

2. Kepada pihak Kementerian agama agar meningkatkan sosialisasi ekaistensi MDT kepada masyarakat, mengkomunikasikan, dan mengkoordinasikan dengan pihak Pemda Rejang Lebong, serta stickbolder yang terkait untuk melahirkan regulasi sebagai pengikat kewajiban mengikuti pembelajaran MDT;

3. Kepada pihak pengelola MDT rangkul semua kekuatan dan mitranya untuk memanfaatkan dengan maksimal potensi faktor pendukung berupa salah satu visi Bupati Rejang Lebong mewujudkan masyarakat Rejang Lebong yang religius dengan mengupayakan lahirnya berupa Perda wajib pendidikan Madrasah Diniyah Takmiliyah di Kabupaten Rejang Lebong;

4. Diharapkan kepada stickbolder dan para pemerhati pendidikan Madrasah Diniyah Takmiliyah untuk memberikan dorongan kepada orangtua yang memilki anak dan atau cucu agar memanfaatkan lembaga MDT dengan maksimal guna memberikan bekal pendidikan agama.

\section{Daftar Pustaka}

Arifin, Zainal, Penelitian Pendidikan Metode Paradigma Baru, Cet. I, Bandung: PT. Remaja Rosdakarya, 2011.

Arikunto, Suharsimi, Prosedur Peneliti: Suatu Pendekatan Praktik. Jakarta: Rineka Cipta, 1998.

Azra, Azyumardi, Reintegrasi Ilmu-ilmu dalam Islam Zainal Abidin Bagir, (ed) Integrasi Ilmu dan Agama: Interpretasi dan Aksi, Bandung: Mizan, 2005.

Azwar, Saifuddin, Metode Penelitian. Yogyakarta: Pustaka Pelajar, 1997.

B. Miles, Matthew, A. Michael Huberman, Analisis Data Kualitatif "Buku Sumber Tentang Metode-Metode Baru. Jakarta: PT.UI-Press, 1992.

Daradjat, Zakiyah, Metodik Khusus Pengajaran Agama Islam, Jakarta: Bum Aksara, 2008.

Departemen Pendidikan Nasional, Tujuan Pendidikan Agama Islam di Sekolah Dasar.

Depdikbud, Kamus Indonesia, Jakarta: Balai Pustaka, 2005.

Depertemen Agama RI, al-Qur`an dan Terjemahnya (al-Qur`an al-Karim), Jakarta: PT. Sinergi Pustaka Indonesia, 2012.

Dirjen Pembinaan Kelembagaan Agama Islam Departemen Agama RI, Pengertian Pendidikan Agama Islam.

El-Rais, Heppi, Kamus Ilmiah Populer, Yogyakarta: Pustaka Pelajar, 2012. Endarmoko, Eko, Tesaurus Bahasa Indonesia, Jakarta: Gramedia, 2009

Erwan Agus Purwanto, cs, Penelitian Kuantitatif untuk Administrasi Publik dan Masalab- masalab Sosial, 2007 
Iskandar, Metodologi Kualitatif, Jakarta: Gang Persada, 2009. 148

J Moleong, Lexy, Metodologi Penelitian Kualitatif. Bandung: Remaja Rosda Karya, 2004.

Kartoredjo, Kamus Baru Kontemporer, Bandung: Rosdakarya, 2014.

Kementerian Agama RI, Panduan Model Pembelajaran Efektif Madrasah

Diniyah Takmiliyah Jakarta: Direktorat Pendidikan Diniyah dan Pondok Pesantren, 2014.

Kementerian Agama RI, Pedoman Penyelenggaraan Madrasah Diniyah Takmiliyah, Jakarta: Direktorat Jenderal Pendidikan Islam, Direktorat Pendidikan Diniyah dan Pondok Pesantren, 2014.

Kementerian Agama RI, Pedoman Penyelenggaraan Madrasah Diniyah Takmiliyah, Jakarta: Direktorat Pendidikan Diniyah dan Pondok Pesantren, 2014.

Kementerian Agama RI, Peraturan Pemerintah Republik Indonesia Nomor

55 Tahun 2007 tentang Pendidikan Agama dan Pendidikan

Keagamaan, Jakarta:Direktorat Pendidikan Diniyah dan Pondok

Pesantren, 2007.

Kementerian Agama RI, Pondok Pesantren dan Madrasah Diniyah Pertumbuhan dan Perkembangan, Jakarta: Direktorat Jenderal Kelembagaan Agama Islam, 2003.

Kuntjoro, Metode Penelitian Masyarakat. Jakarta: PT Gramedia, 1991.

Matthew B. Miles dan A, Michael Huberman, Analisis Data Kualitatif, Buku Sumber Tentang Metode-metode Baru, Jakarta 1992.

Mujib, Abdul, Ilmu Pendidikan Islam Cet II, Jakarta: Kencana Preda Media, 2008.

Mujib, Abdul, Ilmu Pendidikan Islam, Jakarta: Kencana, 2006.

Naimah, Kebijakan Pemerintah Kota Pekalongan Tenang Sekolah Model Pendidikan Agama Islam (Studi Implementasi di SMP N 5 Pekalongan),

Narbuko, Cholid, Metode Penelitian. Jakarta: PT. Bumi Aksara, 2005.

Pusat Pembinaan dan Pengembangan Bahasa, Kamus Besar Bahasa Indonesia, cet.2, Jakarta: Balai Pustaka, 1989.

Rahman Assegaf, Abdur, Filsafat Pendidikan Islam: Paradigma Baru Pendidikan

Hadhari berbasis Integratif-Interkonektif Cet. II, Jakarta: Rajawali Press, 2011. 149

Republik Indonesia, 2003, UU No 20 tahun 2003 tentang sistem pendidikan Nasional. Jakarta: Depdikbud.

S. Nasution, Berbagai Pendekatan dalam Proses Belajar dan Mengajar Cet. XVI, Jakarta: Bumi Aksara, 2013.

S. Nasution, Metode Research Penelitian Ilmiah. Jakarta: Bumi Aksara, 2006. 
Samani, Muchlas, Konsep dan Model Pendidikan Karakter Cet. I, Bandung: PT. Remaja Rosdakarya, 2011

Sugiyono, Metode Penelitian Pendidikan: Pendekatan Kuantitatif, Kualitatif dan R\&D. Bandung: Alfabeta, 2008.

Sunarso, Ali, Islam Praparadigma Cet. I (Yogyakarta: Tiara Wacana, 2009

Syaodih Sukmadinata, Nana, Metode Penelitian Pendidikan, Cet. V, Bandung: PT. Remaja Rosdakarya.

Thoha, Chabib, Metodologi Pengajaran Agama Cet. II, Yogyakarta: Pustaka Pelajar, 2004. 
50 | TADBIR : Jurnal Studi Manajemen Pendidikan, Vol. 2, No. 1, 2018

This page belongs to the TADBIR : Jurnal Studi Manajemen Pendidikan TADBIR : Jurnal Studi Manajemen Pendidikan vol. 2 , no. 1, 2018

STAIN Curup - Bengkulu | p-ISSN 2580-3581; e-ISSN 2580-5037 